\title{
THE FIRST PANCAKE ALWAYS HAS LUMPS: ALBERTA PETROLEUM COMPANIES, ARBITRATION AND ARBITRAL AWARD ENFORCEMENT IN THE RUSSIAN FEDERATION
}

\section{ANTHONY CIONI*}

Alberta petroleum companies stand to benefit a great deal from joint-venture operations in Russia; however, the potential risks involved are enormous as well. This article examines means by which Alberta companies can protect themselves, namely through arbitration agreements, and some important terms that should be drafted into such contracts. As well, an analysis is provided of the arbitration system and some possible outcomes should a dispute arise once an Alberta company has commenced operations in Russia.
Les ententes de coentreprise conclues entre les sociétés d'exploitation pétrolière de l'Alberta et la Russie s'annoncent très prometteuses. Les risques sont néanmoins considérables. Le présent article examine les mesures de protection dont disposent les sociétés albertaines, les conventions d'arbitrage notamment, et certaines des conditions importantes qui devraient figurer dans les contrats de ce type. Il propose également une analyse du système d'arbitrage et des solutions à envisager en cas de différend survenant après qu'une société albertaine a entamé des activités en Russie.

\section{TABLE OF CONTENTS}

I. INTRODUCTION . . . . . . . . . . . . . . . 727

II. HISTORICAL IMPORTANCE OF OIL AND GAS IN THE SOVIET UNION AND THE RUSSIAN FEDERATION $\ldots \ldots \ldots 728$

A. $1970-1990 \ldots \ldots \ldots \ldots \ldots \ldots \ldots \ldots \ldots \ldots \ldots$

B. THE FUTURE OF RUSSIA'S PETROLEUM INDUSTRY

\& WESTERN CAPITAL INVESTMENT . . . . . . . 729

III. ALBERTA'S PETROLEUM INTERESTS IN THE

RUSSIAN OIL AND GAS SECTOR AND THE NEED

FOR SOUND INTERNATIONAL COMMERCIAL

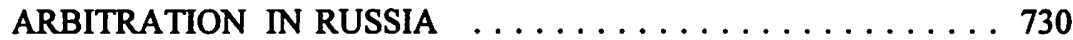

A. ALBERTA INVOLVEMENT $\ldots \ldots \ldots \ldots \ldots \ldots \ldots 730$

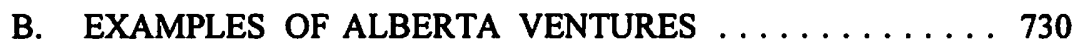

C. THE NEED FOR SOUND INTERNATIONAL

COMMERCIAL ARBITRATION IN RUSSIA ....... 731

IV. RUSSIA'S COURTS AND ARBITRAL TRIBUNALS:

DIFFERENT METHODS OF DISPUTE RESOLUTION $\ldots \ldots 733$

A. THE STRUCTURE OF RUSSIA'S

COURT SYSTEM . . . . . . . . . . . . . 733

B. ASSESSING THE USE OF THE COURTS

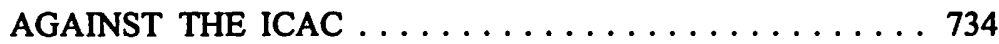

V. ARBITRAL PROCEEDINGS IN RUSSIA - THE ICAC . . . 735

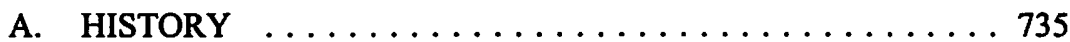

B. LEGISLATION AND RULES GOVERNING THE ICAC . . 736

C. LEGAL ANALYSIS OF PROBLEMS FOUND

IN THE 1993 DECREE AND THE ICAC RULES . . . . . 737

Student-at-law, articled to the firm of Code Hunter Wittmann, Calgary, Alberta. This article won first prize in the general category of the 1997 William Morrow essay contest. 


\section{GENERAL SUMMARY OF ARBITRATING}

WITH THE ICAC . . . . . . . . . . . . . . . 748

VI. ENFORCEMENT OF ARBITRAL AWARDS IN RUSSIA . . . . 748

A. INTERIM MEASURES . . . . . . . . . . . . 748

B. DOMESTIC ARBITRATION ENFORCEMENT ....... 749

C. ENFORCEMENT OF FOREIGN ARBITRAL AWARDS . . 750

D. EXECUTION OF THE ENFORCEMENT ORDER $\ldots \ldots 755$

E. GENERAL PROBLEMS $\ldots \ldots \ldots \ldots \ldots \ldots \ldots \ldots 755$

F. SUMMARY OF THE ENFORCEMENT PROCESS . . . . 756

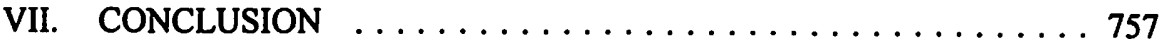

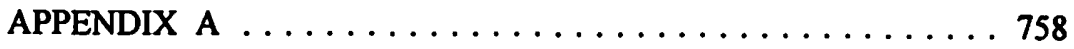

\section{INTRODUCTION}

Historically, from the 8th century kingdom of Prince Rurik to the 1917 Socialist Revolution, Russia has been a land of paradox, instability and struggle. With the fall of the Communist regime in 1991, the country is poised once more to repeat the tumultuous pattern of its past. Proponents of the reformist free market system battle daily with old guard Communists and Nationalists over the future direction of Russia's people and wealth of resources.

During the last days of Communism and throughout Boris Yeltsin's presidency, reformers have pursued a policy of revitalization of the country's main industries through capitalist and free market changes. Under the control of the Communist government, Russia's petroleum sector fell prey to bad policy decisions, leaving it with an aging and inefficient infrastructure. To attract the necessary capital for its rehabilitation, reformers opened Russia's petroleum industry to Western investors and service companies. Many Alberta companies jumped at the chance. The increased participation of Alberta's petroleum industry in Russian ventures gave rise to some serious legal problems. Many of them were of a contractual nature, but to circumvent these difficulties companies still had to grapple with dispute resolution. Given the potential risk to Alberta capital, this issue is of paramount importance.

It may be seriously questioned whether dispute resolution within Russia is a tenable option. Given a recent trend by Russian parties to resolve disputes via international commercial arbitration in their own country, an Alberta party would be wise to know the advantages and disadvantages of arbitrating in Russia and Russian enforcement procedures regarding international commercial arbitration awards made both within and without the Russian Federation.

By way of background information, Part II of this article examines the historical importance of the petroleum industry in the Soviet Union and its current need for rehabilitation. Part III sets out the involvement of three Alberta companies active in the Russian oil and gas sector, while stressing the need for sound international commercial arbitration in Russia. Part IV outlines the structure of the Russian court and tribunal system. Part $\mathrm{V}$ focuses specifically on procedures and rules of the International Commerical Arbitration Court at the Chamber of Commerce and Industry of the 
Russian Federation (ICAC). Finally, Part VI addresses the question of enforcement of arbitral awards, both domestic and foreign, in the Russian courts. The analysis in Parts $\mathrm{V}$ and VI is done from the theoretical standpoint of an Alberta company operating in the Russian Federation.

\section{HISTORICAL IMPORTANCE OF OIL AND GAS IN THE SOVIET UNION AND THE RUSSIAN FEDERATION}

\section{A. $1970-1990$}

Barely a decade ago, the Soviet Union held the centre of the world's petroleum stage. In 1987, it produced approximately 12.48 million barrels of oil per day, surpassing even Saudi Arabia as the largest global producer.' In 1988, Soviet oil production alone amounted to 20.6 percent of world production. ${ }^{2}$ Russia's oil, gas, and coal account for 13 percent of the world's primary energy reserves. ${ }^{3}$ Given the size of the Russian Federation, it is not surprising that approximately 90 percent of Soviet production occurred within Russia, making it the most important of the republics of the former Soviet Union. ${ }^{4}$

However, the 1990s have seen a drastic decline in the state of Russia's petroleum industry. For most of 1993, production averaged only 6.5 million barrels per day. ${ }^{5}$ Overall, production figures plummeted 44 percent between 1988 and $1994 . .^{6}$ Consequently, Russia could no longer rely on petroleum exports to gain the hard currency needed to stabilize its failing economy. ${ }^{7}$ The reasons for the decline are far reaching and pre-date the current political and economic climate of Russia.

V.A. Nesterov, an attache with the Ministry of Fuel and Energy of the Russian Federation, posits that "the steady shortage of capital investment, limitations in equipment and supplies, and overly-ambitious targets for oil production in the 1970s and $1980 \mathrm{~s}$... led to the premature exhaustion of many oil fields." ${ }^{8}$ Commentators note that unrealistically low domestic oil prices set by the Soviets led the Kremlin to rely on the petroleum industry to subsidize other sectors of the economy. ${ }^{9}$ The political myopia of the Soviet government, combined with lack of capital support and the fall of the Communist regime in 1991, eventually brought Russia's petroleum sector to its knees.

K.J. Vaughan, "Russia's Petroleum Industry: An Overview of its Current Status, the Need for Foreign Investment, and Recent Legislation" (1994) 25 Law \& Pol'y Int'l Bus. 813 at 814-15.

L.A. Feathers, "Western Opportunities for Investment in the Oil Industry of the Former Soviet Union" (1992) 7 Am. U.J. of Int'l L. \& Pol.'y 703 at 703.

V.A. Nesterov, "The Petroleum Industry and the Future of Russia" (Summer 1995) 51 Resources: The Newsletter of the Canadian Institute of Resources Law 1 at 1.

Vaughan, supra note 1 at 814 .

Ibid. at 815.

Nesterov, supra note 3 at 1.

Feathers, supra note 2 at 705.

Nesterov, supra note 3 at 1.

Vaughan, supra note 1 at 817-18. 


\section{B. THE FUTURE OF RUSSIA'S PETROLEUM INDUSTRY \& WESTERN CAPITAL INVESTMENT}

Reformers in Russia's petroleum sector now look to the West to provide the capital necessary to rehabilitate the industry, simultaneously stabilizing the Russian economy with the influx of hard currency. Some estimate that Russia will require investments nearing U.S. \$50-60 billion over the next ten years just to stabilize production and exploration. ${ }^{10}$ Meanwhile, others contend that U.S. $\$ 30$ billion will be needed annually for upkeep of present infrastructure, with a further U.S. $\$ 130$ billion needed for the development of new oil fields."

With such drastic numbers, one might wonder why Western companies would want to contribute so much. The answer is the massive potential of the Russian petroleum industry. With roughly 6 percent of the world's oil reserves and 40 percent of its gas reserves, Russia remains a veritable diamond in the rough. ${ }^{12}$ When one considers the proximity of the Eastern Siberian reserves to growing Asian markets, the future benefits of investment become clear. ${ }^{13}$

The Russian Federation has pursued a policy of attracting foreign investment to its oil fields. ${ }^{14}$ The Russian government continues to develop a system of joint-venture legislation begun by the Soviets in the latter days of the Communist regime. However, this system was unbalanced by a host of other problems. The fluctuating rouble, restrictive tax policies, high customs duties, stiff export taxes, corruption and general political and legislative instability have made investors wary. ${ }^{15}$ Although these conditions forced some companies out of Russia, others weighed the risk and decided to stay. ${ }^{16}$

1" Vaughan, supra note 1 at 822.

12 Ibid.; see also Nesterov, supra note 3 at 3: Nesterov points out that a recent Amoco find at the Priobskoje field in Siberia contains reserves of close to five million barrels, around half the size of Prudho Bay, Alaska. Overall, this accounts for about twice the amount of Amoco's other worldwide reserves.

13 See J. Lilley, "Boom-in-Waiting: Sakhalin Fights to Tum its Oil into a Better Life" (1 September 1994) 157:35 Far Eastern Econ. Rev. 28 at 28. If the awaited Sakhalin-2 gas deal goes through, expected investment levels will be around U.S. $\$ 20$ billion.

14 See Decree of the Government of the Russian Federation of June 1, 1992 - No.368, Moscow "On Attraction of Foreign Bank Credits to Gas Industry" in Academy of Jurisprudence of the Ministry of Justice of the Russian Federation, ed., Trade \& Commercial Laws of the Russian Federation, (New York: Oceana Publications, 1993) at 32-33.

is Nesterov, supra note 3 at 2. See K. Hober, "A Game Called Russian Oil: Trading Oil in the FSU - Recent Developments" (1995) 13 J. of Energy \& Nat. Resources L. 96; see also L.E. Wilson, "Operating in the New Russia" (1996) 44:3 Oil \& Gas Tax Q. 249 at 250-54. See also S. Ewart, "Oilpatch Lure: Russian Official Says Taxes Will Be Eased Soon" Calgary Herald (30 November 1996) B12.

16 See Section III below; see also R.H. Pollack, J. G. Dannis \& A.A. Bernstein, "New Opportunities in Russia's Oil and Gas Industry" (1993) 12:5 Int'l Fin. L. Rev. 20. 
The following section briefly outlines the operations of a few main Alberta players involved in ventures and service technology contracts. By examining the involvement of these companies, the importance of Alberta capital risk will become apparent, stressing the need for sound international commercial arbitration in Russia.

\section{ALBERTA'S PETROLEUM INTERESTS IN THE RUSSIAN OIL AND GAS SECTOR AND THE NEED FOR SOUND INTERNATIONAL COMMERCIAL ARBITRATION IN RUSSIA}

\section{A. ALBERTA INVOLVEMENT}

Given Alberta's global reputation in the oil and gas market, Alberta companies were logical business partners when it came to investment and operations in the Russian Federation. Through the use of joint-venture companies, joint-stock companies and service contracts, Alberta companies became involved in the rehabilitation of Russia's petroleum sector. As of the summer of 1995, there were six Canada-Russia jointventures in operation. ${ }^{17}$

\section{B. EXAMPLES OF ALBERTA VENTURES}

\section{Canadian Fracmaster Ltd.}

Fracmaster is a Calgary based company that specializes in the stimulation of unproductive wells through the use of various technical innovations. Having operated in Russia since 1986, this company has extensive work experience in the Russian Federation.

Given the number of unproductive wells in Russia's failing petroleum infrastructure, the match between Fracmaster and Russian companies is quite logical. Fracmaster is currently involved in four joint-ventures in Western Siberia, the proceeds of which yield approximately 10 million barrels of oil per year. ${ }^{18}$ Fracmaster's Supply \& Services sector, and its Fee-for-Service sector, are also steadily increasing. ${ }^{19}$

\section{Dreco Energy Services Ltd.}

Dreco Energy Services Ltd., is an Alberta company that designs and manufactures "machinery, equipment and downhole products for use in the drilling and servicing of oil and gas wells." ${ }^{20}$ Through its various trade names, it is known for the construction of huge stationary land rigs, mobile rigs, offshore rigs, specialized drilling platforms and specialized downhole equipment.

Nesterov, supra note 3 at 3. Telephone interview (10 November 1996) with Dimitri Katsuris, of the Canada-Russia Business Institute. Katsuris estimates investment figures up to 1993 put the total amount of Alberta capital in Russia at U.S. \$300 million. from the shared production of the wells it rehabilitates and not through cash payments.

20 Dreco Energy Services Ltd., Annual Report 1995 at inside cover [hereinafter Dreco Report]. 
Between 1992 and 1995, Dreco shipped some 60 oil rigs to Russia and Kazakhstan and by the end of 1995, it had received contracts for an additional 10 rigs. $^{21}$ To accommodate this activity, the company expanded its Moscow office and opened new centers in Nizhnevartovsk and Ugansk. ${ }^{22}$ Dreco's combined revenue figures from their Russian operations for 1994 and 1995 equaled U.S. $\$ 30$ million. ${ }^{23} 1995$ projections for the following year stood at U.S. $\$ 14.5$ million. ${ }^{24}$ Their downhole products generated similarly impressive revenues. ${ }^{25}$

\section{PanCanadian Petroleum Ltd.}

PanCanadian is a Calgary based oil company which is also involved in operations in the Russian Federation. The company currently owns a 25 percent interest in the Samoltor joint-venture in Western Siberia. ${ }^{26}$ The project, PanCanadian's first abroad, averaged production levels of 4657 barrels per day in $1995 .{ }^{27}$ Figures for the second quarter of 1996 were 6357 barrels per day. ${ }^{28}$ Overall, PanCanadian has invested Cdn. $\$ 39.3$ million into its Russian operations since 1991, and planned to spend an additional Cdn. $\$ 8$ million in $1996 .{ }^{29}$

\section{THE NEED FOR SOUND INTERNATIONAL COMMERCIAL ARBITRATION IN RUSSIA}

Given the potential risk to the capital investments described above, Alberta companies need recourse to predictable and reliable international commercial arbitration..$^{30}$ As legal scholar Piero Bernardini points out, "[the] lack of attention [to dispute resolution] is usually explained by the fact that the negotiators of both parties tend to concentrate their efforts on the economic, financial and commercial terms of the deal ... delay[ing] what they consider to be simply one of several 'boiler-plate' clauses. ${ }^{.31}$

Considering the potential risk to capital in Russian investments, it is clear that the choice of a dispute resolution mechanism is far from a "boiler-plate" issue. ${ }^{32}$ Another expert points out that international commercial arbitration can be a very useful tool in

21

22

23

24

Ibid. at 3.

Ibid.

Ibid. at 15.

Ibid.

Ibid.

PanCanadian Petroleum Ltd., Annual Report 1995 at 21 [hereinafter PCP Report]. The Samoltor field is the third largest in the world.

Ibid.

PanCanadian Petroleum Ltd., "News Release: Second Quarter - 1996 - Report to Shareholders" (22 July 1996) at 2.

PCP Report, supra note 26 at 21 .

For a description of debt crisis see C.T. Ebenroth \& T.J. Dillon, Jr., "Arbitration Clauses in International Financial Agreements" (1993) 10:2 J. Int'। Arb. 5 at 5.

P. Bernardini, "The Arbitration Clause of an International Contract" (1992) 9:2 J. Int'l Arb. 45 at 45.

M. Pryles, "Drafting Arbitration Agreements" (1993) 67 Aust. L.J. 503 at 503. 
the settlement of long-term contracts. ${ }^{33}$ The lengthy orientation of most large petroleum production deals underscores the need for sound international commercial arbitration.

In the 1970s and 1980s, Western companies were quite successful in securing arbitration in neutral venues from their Soviet counterparts, ${ }^{34}$ following the generally prudent rule of thumb, never fight in your neighbor's yard. ${ }^{35}$ However, this trend may be changing.

One practitioner working in Russia notes a counter-trend in Russian attitudes and a "resistance growing throughout the former Soviet Union to the use of Stockholm and other Western cities as arbitration venues." ${ }^{13}$ A Kazakh company unfavorably settled its differences with a German partner rather than arbitrate in the West. ${ }^{37}$ In doing so, it cited the costs of arbitrating abroad for cash-starved companies in the former Soviet Union (FSU). Moreover, it was suggested that Moscow was a far more preferable site. $^{38}$

The traditional contention has been that arbitration in Russia is unacceptable to the interests of Alberta companies. However, what if the counter-trend to arbitrate in Russia grows in strength? Fracmaster's legal counsel, Derek Worden, recently commented that Fracmaster was fortunate enough to avoid arbitration in Russia. ${ }^{39}$ However, what if Alberta companies had to agree to arbitration in Russia in order to gain licensing agreements from the powerful Russian government? ${ }^{40}$ What exactly are the benefits and detriments of such a process? If certain difficulties are ascertainable, can a company carefully draft its arbitration clause to avoid pitfalls? What of domestic or foreign arbitral award enforcement?

These concerns were echoed in a recent draft report to the Canada-Russia Intergovernmental Economic Commission. The Canada-Eurasia Energy and Industry Alliance (CEEIA) suggests, "the enhancement of an effective dispute resolution mechanism." ${ }^{41}$ The CEEIA continues, "[w]hat is required is that disputes must be

V. Viechtbauer, "Arbitration in Russia" (1993) 29 Stan. J. Int'l L. 355 at 397.

E. Horváth, "Arbitration in Central and Eastern Europe" (1994) 11:2 J. Int'l Arb. 5 at 6-7.

Bernardini, supra note 31 at 52.

"East-West Trade: Russia's Failure to Pay Western Firms Leads to Arbitration Explosion, Expert Says" (1993) 10 Int'l Trade Rep. 529 [hereinafter "Arbitration Explosion"] in S.G. Zinger, "Navigating the Russian Shipping Industry: Making the Most of International and Russian Law for Successful Arbitration Against Russian Parties" (1995) 8:1 U. San Fran. Maritime L.J. 141 at 157.

Ibid. The burdens of a costly arbitration in the West on Russian companies with little or no hard currency are confirmed by Viechtbauer, supra note 33 at 368.

lbid.

Telephone interview (12 November 1996) with Derek Worden, partner Davison Worden.

Dreco Report, supra note 20 at 2-3. Due to the late delivery of product to a Norwegian company, Dreco faced the possibility of binding arbitration.

CEEIA, Position Paper for IEC Conference: A Proposal at 2 [draft]. The Canada-Russia Intergovernmental Economic Commission is a communicative forum for both Russian and Canadian businesses to express their respective needs and concerns. 
expeditiously and judiciously resolved, winning the respect of both parties for impartial and informed decision-making." ${ }^{42}$

Part $\mathrm{V}$ examines the practices and procedures of the International Commercial Arbitration Court (ICAC) in Moscow, and attempts to identify potential problems for Alberta companies. Contractual drafting suggestions will be made to help Alberta companies side-step procedural problems.

Before any analysis of arbitration procedures is done, a brief inquiry into Russia's court system should be undertaken to ascertain the jurisdictions of the various judicial bodies. In addition, the advantages of international commercial arbitration at the ICAC over litigation in Russia's courts will be discussed.

\section{RUSSIA'S COURTS AND ARBITRAL TRIBUNALS: DIFFERENT METHODS OF DISPUTE RESOLUTION}

\section{A. THE STRUCTURE OF RUSSIA'S COURT SYSTEM}

After the fall of the USSR, Russian reformers set about revamping the courts. The creation of new courts with new jurisdictions caused some measure of confusion. ${ }^{43}$ To simplify matters, only the two bodies relevant to contract litigation and international commercial arbitration will be examined. ${ }^{44}$ By making reference to the chart in Appendix A, the reader will more easily discern the structure of the Russian court system.

\section{The State Arbitration Courts}

The general jurisdiction of the State Arbitration Court (SAC) covers civil and administrative proceedings and hearings of economic and administrative disputes. ${ }^{45}$ Traditionally, the SAC resolved disputes between Soviet state enterprises but, with the fall of the Soviet Union, it took on the character of a specialized commercial court. ${ }^{46}$ Until recently, the SAC could only hear suits involving foreign parties, where the contract in question granted the SAC jurisdiction over the matter. This would be analogous to an Alberta contract with an Ontario company giving exclusive jurisdiction

12 Ibid.

43 K. Hobér, Enforcing Foreign Arbitral Awards Against Russian Entities (New York: Transnational Juris Publications, 1994) at 31-33.

4. Due to the vast and culturally heterogeneous nature of the Russian Federation, there are many different courts in the autonomous republics, regions and cities. The powers of these courts are created and defined by the Russian Constitution. Therefore, litigation and applications for arbitral enforcement may be under a court of different name depending on the place the party commences the action. The finer points of the Russian court structure are not within the scope of this article. A clearer picture is presented in ibid. Ibid. at 34-36.

46 Ibid. at 35 
over litigation to the courts of Alberta. ${ }^{47}$ In the absence of such an agreement, the suit would have fallen under the jurisdiction of the Courts of General Jurisdiction (CGJ). ${ }^{48}$

However, new changes to the SAC subject almost all commercial disputes to its jurisdiction, even when they involve international parties. ${ }^{49}$ Therefore, it appears that if an Alberta company wished to sue a Russian entity, it would do so in the SAC.

\section{The Courts of General Jurisdiction}

The CGJ remains the court of general jurisdiction over civil and economic matters. The Russian Soviet Federated Socialist Republic Code of Civil Procedure (Russian Civil Code) provided, via art. 25, that all economic and administrative disputes involving foreign businesses must be heard by the CGJ. ${ }^{50}$ Nonetheless, due to the recent changes described above, the CGJ seems to have lost its traditional jurisdiction to the SAC, lessening its attractiveness to Alberta companies.

\section{The Supreme Courts}

In relation to Alberta companies, the Supreme Courts hold considerable importance. Under the 1988 Soviet Decree "On the Recognition and Execution in the USSR of Decisions of Foreign Courts and Arbitral Tribunals," the Supreme Courts hold jurisdiction over applications to enforce foreign arbitral awards. ${ }^{51}$ This will take on further significance in Part VI of this discussion.

\section{B. ASSESSING THE USE OF THE COURTS AGAINST THE ICAC}

Litigating in any foreign national jurisdiction can be undesirable. However, with the legal and social uncertainties of today's Russia, litigation in Russian courts is a very tenuous process.

First, the relative inexperience of the courts in complicated commercial matters makes them unpalatable. One Russian judge was even quoted as saying, "Our judges never dealt with disputes on money, shares or bankruptcies. We can't help foreign investors when we have no rules for the game. We can't protect them from fraud." ${ }^{52}$

47 V. Kozhokar, "Rules of the Game: The System of Courts of Arbitration in the Russian Federation" (1994) 1 Russian Bus. Monitor 21 at 22-23.

48 See: Part $\operatorname{IV}(A)(2)$ below for a description of the Courts of General Jurisdiction.

49 E. Kirillova \& N. Aitken, "Opening Russia's Courts to the World" (2 February 1996) Int'l Comm. Lit. 2.

so Ibid.

st Vedomosti Verkhovnogo Sovieta 1988, No. 26 item 427 [hereinafter 1988 Decree] in Hobér, supra note 43 at 14.

32 Statement by Mikhail Yukov, first Vice-President of the Supreme Court of Arbitration, in E. Kaban, "Russian Courts Have Guns, But No Share Laws" Reuters Financial Services (5 April 1995) available in LEXIS, World Library, ALLWLD File, (Zinger, supra note 36 at 172). 
Second, by litigating in Russia's national courts, an Alberta company might expose itself to the mandatory rules of law of the Russian legal system (e.g. State Immunity, Act of State, etc.)..$^{53}$

Third, an Alberta company suing in a Russian court would have to contend with the widespread corruption of the Russian bureaucracy. ${ }^{54}$

Because of these disadvantages, international commercial arbitration is the most preferable option available in Russia. By using the ICAC, the most experienced international commercial arbitration body in Russia, an Alberta company can rely, to some degree, on a structural and procedural basis for dispute resolution. ${ }^{55}$ The ICAC possesses a rather "'active and largely distinguished' history dating back to the early 1930s." ${ }^{156}$

\section{ARBITRAL PROCEEDINGS IN RUSSIA - THE ICAC}

\section{A. HISTORY}

1. $1932-1993$

On June 17, 1932, the Soviet Government created the Arbitration Court attached to the Soviet Chamber of Commerce and Industry (SCCI) to deal with disputes between Soviet foreign trade entities and Western companies. ${ }^{57}$ The use of the SCCI continued to grow into the 1960s, but as business with the West increased in the 1970s, powerful Western parties began to demand arbitration outside the Soviet Union. ${ }^{58}$ This trend continued in the 1980s and was further accelerated by the fall of the Soviet Regime in 1993..$^{59}$

Despite its declining use and its affiliation with the Soviet government (the SCCI was under the direct control of the Ministry of Foreign Trade), the SCCI established a fairly good reputation for impartiality in the arbitration world. ${ }^{60}$

2. 1993 - Present

In order to modernize the SCCI and make it attractive to Western companies, the Russian government made several changes to the arbitration body over the course of

M. Ball, "Just Do It — Drafting the Arbitration Clause in an International Agreement" (1993) 10:4

3. Int'l Arb. 29 at 30.

See infra Part VI(E).

"Arbitration Explosion," supra note 36 at 1.

lbid.

Viechtbauer, supra note 33 at 365 .

Ibid. at 366.

Ibid.

Ibid. 
the past few years. The passing of the Law on Commercial Arbitration of July 7, $1993^{61}$ brought arbitration in Russia up to speed with international practices by implementing the 1985 UNCITRAL Model Law on International Commercial Arbitration. As well, the Russian government removed the SCCI from the authority of the Minister of Foreign Trade and placed it under the control of the Chamber of Commerce and Industry of the Russian Federation, thereby changing its name to the ICAC. ${ }^{62}$ Finally, to further the implementation of the UNCITRAL Model Law, the ICAC adopted new rules, effective as of May $1,1995 .{ }^{63}$

\section{B. LEGISLATION AND RULES GOVERNING THE ICAC}

\section{The 1993 Decree}

As mentioned, the 1993 Decree enacted the UNCITRAL Model Law, but what does the Model Law constitute? The United Nations Commission on International Trade Law (UNCITRAL) designed the rules as a malleable framework for arbitration procedure. ${ }^{64}$ Over the years, the popularity of UNCITRAL's flexible rules made it virtually the international norm for arbitration. ${ }^{65}$ The 1993 Decree brought the ICAC within these standards.

To establish jurisdiction, art. 1 of the 1993 Decree empowers the ICAC to hear matters dealing with contractual disputes involving foreign companies. It also has jurisdiction to deal with disputes arising between entities with foreign investment, international associations, and organizations established within the Russian Federation. ${ }^{66}$ Curiously, this means that an argument between two Russian companies, where one is partially owned by foreign interests, must be settled by the ICAC and not by domestic arbitration.

Article 10 provides that if the parties fail to determine the number of arbitrators in their agreement, the number shall be three. ${ }^{67}$ The 1993 Decree sets out rules on the following: the arbitration agreement (Part II), the composition of the arbitration court (Part III), the competence of the arbitration court (Part IV), the arbitration proceedings (Part V) and the award and termination of proceedings (Part VI). ${ }^{68}$ Part VII of the 1993 Decree stipulates that all domestic awards are final and may only be set aside by procedural defects. Finally, Part VIII sets out the grounds for refusal to enforce foreign

Law of the Russian Federation: On International Commercial Arbitration [hereinafter 1993 Decree] in Fin. \& Bus. News (8-14 October 1993) 9.

Zinger, supra note 36 at 166.

The International Commercial Arbitration Court (ICAC) at the Chamber of Commerce and Industry of the Russian Federation, [hereinafter ICAC Rules] in (1995) 11 Arb. Int'l at 197.

J.D. Franchini, "International Arbitration Under the UNCITRAL Arbitration Rules: A Contractual Provision for Improvement" (1994) 62 Fordham L. Rev. 2223 at 2223. It is notable that the UNCITRAL Model Law replicates the New York Convention provisions on the recognition and enforcement of arbitration agreements and foreign arbitral awards. See Part VI(C)(1)(c), infra.

Ibid.

1993 Decree, supra note 61.

lbid.

Ibid. 
arbitral awards ${ }^{69}$ It is noteworthy that both Part VII and VIII are recreations of the grounds for refusal under the $1958 \mathrm{New}$ York Convention on the Recognition and Enforcement of Foreign Arbitral Awards (New York Convention) that will be discussed in detail in Section VI of this article. ${ }^{70}$

\section{The ICAC 1995 Rules}

In 1995, the ICAC drafted new rules to further the implementation of the Model Law. The ICAC Rules detail the inner workings of the tribunal under three main sections: General Provisions, Organization, and Work and Arbitration Proceedings." These three sections provide specific fiats on everything from confidentiality to evidentiary procedure and arbitration fees.

\section{LEGAL ANALYSIS OF PROBLEMS FOUND IN THE 1993 DECREE AND THE ICAC RULES}

The legal analysis of the problems centered around the 1993 Decree and the ICAC Rules will be based on traditional criticisms of arbitration in Russia and the Soviet Union. ${ }^{72}$ The aim is to examine the validity of each of these complaints. During the course of this investigation, this article will: (1) identify the problems; (2) determine if the new rules and laws differ from the old Soviet rules; and (3) suggest drafting techniques for the arbitration agreement that might protect an Alberta company.

\section{Applicable Law and the Lex Arbitri}

\section{a. Validity of the Arbitration Clause}

Under the doctrine of separability, traditional Western legal thinking considers the arbitration agreement separate and independent from the main contract. ${ }^{73}$ In this way, if a contract is void for some defect, an arbitration may still proceed on the basis that the arbitration agreement is in force. ${ }^{74}$ The ICAC Rules clearly follow this Western approach. $^{75}$

However, what if the arbitration agreement itself is invalid? Problems arise where the parties have not stated a choice of law applicable to the question of the validity of the arbitration agreement. Absent a choice of law clause, the question becomes: which country's laws determine the validity of the arbitration agreement? Several different

\footnotetext{
69 Ibid.

70 New York Convention on the Recognition and Enforcement of Foreign Arbitral Awards, 10 June, 1958 [hereinatter New York Convention].

"ICAC Rules, supra note 63 at 197-217.

$n$ Some of the problems examined are based on those found in: A.J. Koman, "Arbitrating Among the Russians" (February 1995) Fed. Lawy. 26; and Zinger, supra note 36.

$n$ Koman, ibid. at 30.

$74 \quad$ Viechtbauer, supra note 33 at 383.

75 ICAC Rules, supra note 63 at $198 \S 1(5)$.
} 
theories currently circulate in Western fora. ${ }^{76}$ The Russian, and former Soviet approach, seems quite decided on this point. Viechtbauer notes that, in the absence of a statement governing applicable laws, Soviet courts usually characterized themselves as the lex fori and applied Soviet conflicts law to the question of validity. ${ }^{77}$ If this were still the case and the ICAC adjudged an arbitration agreement to be invalid and unarbitrable, an Alberta party might fear their involvement in a civil suit in the SAC.

To quell this fear, the Russian government gave the ICAC the power to "pass a ruling ... [concerning the] validity of the arbitration agreement. ${ }^{178}$ Article $16(3)$ of the 1993 Decree declares that such a ruling may be made "as on a preliminary issue or as on the matter in dispute."179 This article provides a further right to appeal the ruling to a Russian court within thirty days. ${ }^{80}$ Although the 1993 Decree does not completely exclude the courts, it does make the ICAC the forum of first instance. Given the superior expertise of the ICAC over the Russian courts, this step is an improvement over the former state of affairs. However, the general uncertainty of the Russian legal system makes it impossible to obtain predictable results on the validity of arbitration agreements. $^{81}$

The most practicable method of avoiding the problematic application of Russian law to the validity of the arbitration agreement is to stipulate the laws under which validity should be determined. To omit this contractual declaration is an error of the highest order because it could land an Alberta company in the very Russian courts it sought to avoid. $^{82}$

\section{b. The Proper Law of the Contract}

In the context of arbitration, the proper law of the contract is the set of laws, chosen by contracting parties, which governs the substantive issues of the arbitral proceedings.

If parties who wish to arbitrate in Russia neglect to stipulate a proper law of the contract in their arbitration agreement, the matter must be decided by the ICAC. The 1993 Decree states that in the absence of a statement on the proper law, the ICAC "shall apply the law as determined according to the conflict rules which it thinks are applicable." ${ }^{83}$ Similarly, the ICAC Rules indicate that where no agreement is reached on the proper law, "the ICAC being abided by [sic] the provisions of the Russian law relating to international commercial arbitration shall carry out the proceedings in such

\footnotetext{
76 Koman, supra note 72 at 30.

$77 \quad$ Viechtbauer, supra note 33 at 383.

73 1993 Decree, supra note 61, art. 16(1).

79 lbid.

so Ibid.

si Koman, supra note 72 at 30.

82 Ibid. Traditionally, the SCCI and ICAC have not extended the choice of law clause on the proper law of the contract to cover the validity of the arbitration agreement.

1993 Decree, supra note 61, art. 28(2).
} 
a manner as it thinks fit. ${ }^{1184}$ At the very least, this leaves Alberta companies at the mercy of Russian conflicts rules.

Russian conflicts laws, and those of the Soviet Union, are divisive, as they call for the application of two different rules. Article 566 of the Russian Civil Code states that in the absence of a declaration on the proper law, a foreign contract is governed by the laws of the place were the contract is signed, or the loci contractus. ${ }^{85}$ Meanwhile, the Fundamentals of Civil Procedure state that the proper law, absent an agreement, will be determined by the state of incorporation. ${ }^{86}$ Although it is not within the scope of this article to deal with the eccentricities of Russian conflicts law, this ambiguity underscores the general legislative confusion of the country. It also underscores the continued importance of careful drafting in the arbitration agreement to avoid such legal pitfalls.

To augment the turmoil, Koman notes that the discretion given to the ICAC invariably leads to the application of Russian law as the proper law of the contract. ${ }^{87}$ Neither the ICAC, nor the SCCI, have made recourse to such Western notions as the "intended will of the parties" to determine the proper law. ${ }^{88}$ By omitting a statement on the proper law of the arbitration agreement, Russian legal concepts will most likely apply.

When one considers the complex nature of petroleum contracts, the undesirability of Russian law as the proper law becomes even clearer. Consequently, Alberta petroleum companies ought to bargain for Alberta law as the proper law of the contract. Alternatively, an Alberta company might insist on the rules of other common law jurisdictions, such as Texas, Oklahoma or the United Kingdom, which have some expertise in the area of petroleum litigation. ${ }^{89}$

Finally, although a remote possibility, it is conceivable that the application of Russian law in an arbitration hearing might include certain mandatory or public policy rules that do not directly relate to contract or petroleum law itself. The danger here would be the reliance of a Russian party on a "public policy" argument exonerating it from its debts (e.g. Act of State). Given the legal disorder of the Russian system, some of these concepts are not fully developed, leaving much to the interpretative imagination..$^{90}$ Although this question remains remote, it nonetheless raises the specter of yet another danger to Alberta companies.

ss M. Bardina, "Some Aspects of Russian Legislation Relevant to Foreign Economic Relations" (1993-1994) 5 Jurid. Tids. 667 at 673.

86 Ibid. The Fundamentals of Civil Procedure are the set of civil rules created by the Soviets before the fall of the regime in 1991.

Koman, supra note 72 at 30.

Viechtbauer, supra note 33 at 407.

J.I. Huhs \& R.A. Beridze, "Dispute Resolution in Russia" (November 1992) Am. Lawy. 33 at 33. For a general discussion on the relationship between the lex contractus and rules of public policy see D. Hochstrasser, "Choice of Law and 'Foreign' Mandatory Rules in International Arbitration" (1994) 11:1 J. Int'l Arb. 57. 
In sum, the ramifications of omitting a choice of law clause in an arbitration agreement are clearly disastrous. The absence of such a clause would leave an Alberta party at the potential whim of confused Russian/Soviet conflicts principles, undeveloped Russian/Soviet petroleum and contract laws, and mandatory public policy rules. The easiest way to avoid these legal headaches is to draft a clause on the proper law of the contract that best reflects the interests of the Alberta company.

\section{c. Ex Aequo et Bono, Lex Mercatoria, and Commercial Practice}

One commentator writes, "the law of equity is a particular branch of Anglo-American law unknown in continental systems - including the Russian system."191 It seems fairly certain that the ICAC will not decide cases on ex aequo et bono, principles of equity, lex mercatoria (general principles of commercial law), or commercial practice. Article 33 of the UNCITRAL Model Law, which gives arbitrators the power to depart from the applicable law to decide matters with these general legal principles, is notably absent from the 1993 Decree. ${ }^{92}$ Furthermore, the ICAC Rules are also silent on the application of equitable principles. This omission represents a long-standing attitude of the Russian legal system towards equity. ${ }^{93}$

In terms of lex mercatoria, the result is similar. Viechtbauer notes that the SCCI did not have the power to decide an arbitration "according to general principles of law." ${ }^{94}$ Moreover, lex mercatoria and commercial practice are arguably two legal concepts that have not sufficiently developed to warrant their application. ${ }^{95}$

At first glance, the absence of equitable grounds would seem to be a disadvantage to companies based in such common law jurisdictions as Alberta. However, scholars posit that the application of equity might actually be disadvantageous. ${ }^{96}$ When negotiating an arbitration agreement, the parties may wish to rely on the predictable set of rules offered by the proper law of the contract, and not by more malleable equitable standards. ${ }^{97}$ Here again, the problem is solved by a careful choice of proper law and good drafting in the arbitration agreement.

\section{d. Expert Evidence on Foreign Laws}

Even if an Alberta company carefully stipulated a choice of law foreign to the Russian system, the fiats of that foreign law would still have to be interpreted by the

V.A. Dozortsev, "Trends in the Development of Russian Civil Legislation During the Transition to a Market Economy" (1993) 19 Rev. Cen. \& East Euro. L. 513 at 521.

Koman, supra note 72 at 32 . Here, Koman notes a discrepancy between the 1993 Decree and art. 28 of the UNCITRAL Model Law. However, it seems that this observation is more applicable to art. 33 than to art. 28.

$93 \quad$ Bernardini, supra note 31 at 53.

94 Viechtbauer, supra note 33 at 408. 
ICAC. Considering that the ICAC arbitrators might be unfamiliar with the particular rules of the proper law of the contract, it follows that expert evidence would be a logical means of educating the tribunal. In Soviet times, when all the arbitrators were of Soviet nationality, this problem was especially pronounced, because the arbitrators had little experience with Western legal concepts. It was only with the advent of the 1993 Decree that the appointment of expert witnesses became possible. In the absence of an agreement between the parties, art. 26 gives the ICAC the power to appoint experts. $^{98}$ That same article gives the parties an opportunity to put questions to the expert and to adduce evidence through their own specialists. ${ }^{99}$

Although these provisions seem to give the parties the right to adduce their own evidence, via specialist testimony on the proper law of the contract, it is unclear from the wording of the section whether this right is contingent on the initial appointment of an expert by the ICAC. The 1993 Decree is equivocal on whether the ICAC must first call an expert before the parties may call their own specialists. The same ambiguity is noted in the wording of the UNCITRAL Model Law and the interpretive answer is still obscure. ${ }^{100}$

The best way for an Alberta company to avoid this debacle is, again, through prudent drafting. In theory, art. 19 of the 1993 Decree allows the parties to amend the arbitral proceedings. In doing so, they may wish to incorporate the right of the parties, independent from that of the ICAC, to call experts on the proper law of the contract.

Despite the new law in the 1993 Decree, it will take some time to see if the ICAC abandons the self-reliant practices of its predecessors on questions of foreign law interpretation. ${ }^{101}$ In the meantime, an Alberta company can protect itself by drafting amendments to the arbitral proceedings into the arbitration agreement.

\section{Procedural Matters of the ICAC}

\section{a. Procedures}

As mentioned in the previous section, the parties have the express right to amend the arbitral proceedings. The proper view of art. 19 is that the 1993 Decree acts as a set of default rules when the arbitration agreement fails to address certain basic issues. ${ }^{102}$ This is a major change from the SCCI, which would only apply different procedures if they were not at variance with Soviet rules. ${ }^{103}$

The character of the ICAC remains very formal. Partially due to the formality of its predecessor and partially due to its semi-official status (the ICAC was created by the

1993 Decree, supra note 61, art. 26(1).

Ibid., art. 26(2).

Franchini, supra note 64 at 2241.

Koman, supra note 72 at 31.

Ibid.

Viechtbauer, supra note 33 at 401. 
Russian government), the ICAC strictly applies procedural and substantive provisions. ${ }^{104}$ Further, it prefers specific performance to damage awards, quite unlike its Western counterparts. ${ }^{105}$ Even with the more relaxed standards of the 1993 Decree, the ICAC remains a very formal setting. It may take some time, if ever, for the new rules to affect the long-standing traditions of the arbitration board.

\section{b. Procedure for Challenging ICAC Arbitrators}

Throughout the entire history of the ICAC and the SCCI, there has never been a recorded case of one of the parties challenging an arbitrator. ${ }^{106}$ Considering that an international commercial arbitration board has been operating in Moscow since 1932, hearing a total of more than 4,000 cases, this fact is quite astounding. ${ }^{107}$ This fact is even more amazing when one considers that in each case all of the arbitrators were Soviets, and therefore foreign to one of the parties.

In theory, the challenging of arbitrators is provided for in art. 12 of the 1993 Decree. This fiat states that "The arbitrator may be challenged only in case there are circumstances which may cause reasonable doubts in respect of his impartiality or independence, or in case he does not possess the skills required under the parties' agreement.."108 The problem here is not the absence of a legal right to challenge the arbitrator, but rather the pure novelty of such a complaint. ${ }^{109}$

Article 12(1) requires arbitrators to disclose any conflicts of interest that might affect their impartiality, independence or level of experience. ${ }^{110}$ Although the requirement of disclosure is an improvement over the pre-1993 Decree state of affairs, there are still practical considerations when it comes to conflict of interest. Corruption is endemic in today's Russian society, and the independence and impartiality of a Russian arbitrator may be threatened by bribery."'

\section{c. Transcripts of the Arbitration}

A seemingly small detail, the accuracy and length of transcripts might seriously affect an Alberta company's ability to challenge the procedural fairness of the proceedings. Traditionally, Russian courts and tribunals do not provide verbatim records of the proceedings. Rather, they offer "summaries," something akin to the minutes from a meeting. ${ }^{12}$ In a long and complicated arbitration, these summaries may omit subtleties entailing a denial of procedural fairness that could give rise to an appeal from

\footnotetext{
104 Koman, supra note 72 at 31.

105 Ibid.

106 Viechtbauer, supra note 33 at 404.

107 Koman, supra note 72 at 29.

10893 Decree, supra note 61, art. 12(2).

109 Koman, supra note 72 at 29.

1101993 Decree, supra note 61 , art. 12(1).

11 Zinger, supra note 36 at 167.

$112 \quad$ Koman, supra note 72 at 29.
} 
the award rendered. ${ }^{113}$ The ICAC Rules, $\S 5(1)$, declare that the Chairman of the ICAC shall appoint a reporter for each case. ${ }^{114}$ Further, $\S 5(2)$ of the ICAC Rules stipulates that the Presidium of the ICAC shall keep an official list of reporters, to be reviewed every five years. ${ }^{115}$ It is unclear whether this means that the Chairman must choose a reporter from the list, or whether an Alberta party might provide for the services of Western reporters.

The ICAC Rules, § 37, set out the basic requirements for transcripts and give the parties the right to request amendments or supplements to the record. ${ }^{116}$ It is not clear whether the parties can request verbatim transcripts of the arbitration proceedings or just more detailed "summaries."

\section{d. Disclosure Between the Parties}

Prior to the 1993 Decree, there was no compellable or institutionalized process for disclosure between the parties. ${ }^{117}$ Information, when provided, was exchanged primarily out of goodwill. ${ }^{118}$ The current law states, "All statements, documents and other information furnished by one of the parties to the arbitration court shall be presented to the other party." 119 The ICAC Rules provided for the same right of disclosure between the parties. ${ }^{120}$ This represents an improvement, but if an Alberta company desires a formal discovery process, it could amend the arbitral proceedings in its arbitration agreement accordingly. ${ }^{121}$

\section{e. Evidentiary Procedures}

Evidentiary procedures in arbitration hearings tend to be much more informal than those of the courts. Viechtbauer points out that the SCCI's provisions governing evidentiary matters were scant and did not cover complex issues dealing with expert evidence and affidavits. ${ }^{122}$ This is true of both the 1993 Decree and the ICAC Rules. These concerns, and others such as the right to cross-examine, can be addressed in the arbitration agreement. Alberta companies can include more complicated evidentiary procedures to assure themselves of the ability to fully present their case.

On the question of compelling witnesses, the parties may apply for a subpoena in a Russian court per art. 27 of the 1993 Decree. ${ }^{123}$ Although this provides a theoretical backdrop for judicial assistance in the collection of evidence, an Alberta company

Ibid. Procedural appeals will be discussed in more detail in Part VI of this article.

ICAC Rules, supra note 63 at $\S 5(1)$.

Ibid. at $\S 5(2)$.

ICAC Rules, supra note 63 at $\S 37(1) \&(2)$.

Ibid.

Ibid.

1993 Decree, supra note 61, art. 24(3).

ICAC Rules, supra note 63 at $\$ 29$.

1993 Decree, supra note 61, art. 19(1).

Viechtbauer, supra note 33 at 404.

1993 Decree, supra note 61, art. 27. 
would again be left at the mercy of the inexperienced general courts; potentially on complicated evidentiary matters. Unfortunately, according to the wording of art. 27, there do not seem to be any drafting options available to circumvent this problem.

\section{The Arbitrators}

a. The Arbitrators List: Does it Allow for Foreigners?

Before the implementation of the 1993 Decree, this area was problematic for Western parties and seriously affected the impartial reputation of the Soviet arbitration tribunal. The old rules required that all arbitrators be chosen from an official list, reviewed every four years by the Presidium of the SCCI. ${ }^{124}$ Furthermore, membership on this list was restricted solely to Soviet citizens. ${ }^{125}$

To correct this situation, the 1993 Decree provided for the inclusion of foreigners on the arbitration list: "No person may be deprived of the right to act as an arbitrator by reason of his/her nationality." ${ }^{126}$ In any case, $\S 2(3)$ of the ICAC Rules states that persons who are not on the list may still act as arbitrators. ${ }^{127}$ In theory, this should allow for the legal right of an Alberta party to request the inclusion of a Western arbitrator on the list of arbitrators. However, the Russian practice does not parallel the openness of the 1993 Decree. ${ }^{128}$ In fact, the ICAC has turned away Westerners applying for membership on the arbitration list irrespective of their qualifications. ${ }^{129}$

In a panel of three arbitrators, even if an Alberta party is successful in naming a Westerner, that person and the Russian arbitrator (presumably appointed by the other side) must still choose a third person to chair the arbitration. If no consensus can be reached between the two arbitrators on the third appointment, then the Chairman of the ICAC must select a third person for the task. ${ }^{130}$ Koman posits that if the Chairman were to appoint another Russian to chair the arbitration, then the Western arbitrator could always be outvoted by a 2-1 margin. ${ }^{131}$ However, pursuant to art. 11(5) of the 1993 Decree, the Chairman may only appoint a person who is not a citizen of the country of either party involved in the arbitration. ${ }^{132}$

Overall, the interests of an Alberta company arbitrating at the ICAC seem well served. Any additional concerns, such as the inexperience of the arbitrators, could be addressed through the arbitration agreement.

\footnotetext{
124 Viechtbauer, supra note 33 at 370.

Horváth, supra note 34 at 10.

1993 Decree, supra note 61, art. 11(1).

ICAC Rules, supra note 63 at $\$ 2(3)$.

Koman, supra note 72 at 28.

Ibid.

1993 Decree, supra note 61, art. 11(3).

Koman, supra note 72 at 28.

1993 Decree, supra note 61, art. 11(5).
} 


\section{b. Ideological Orientation of the Russian Arbitrators}

Many of the Russian arbitrators of the current ICAC occupy the same positions they held under the SCCI. Koman observes that "[i]t was a fact of life in the Soviet Union that, except in highly unusual situations, the only people who ever actually acquired prestigious positions were either Party members or individuals who at least frequently and publicly affirmed the principles that the Party stood for."133

In the past, this was of greater concern, as the Communist government exercised control over the SCCI. ${ }^{134}$ However, with the fall of the Soviet Union and the creation of the Russian Federation this concern is somewhat anachronistic. ${ }^{135}$

What may be a more relevant concern is the spread of corruption throughout the Russian Federation. As discussed above, Western parties might well be legitimately concerned about bribery or threats to an arbitrator. ${ }^{136}$ Obviously, this is a reality of life in Russia and no amount of drafting can insulate an Alberta company.

\section{The Place of Arbitration}

Prior to the new rules, the seat of arbitration was always in Moscow. ${ }^{137}$ The 1993 Decree allows parties the complete freedom to move the seat to wherever they choose..$^{138}$ In the absence of such an agreement, the ICAC may choose a site for the administration of the proceedings "as it thinks proper." ${ }^{139}$ In the absence of an agreement on the arbitral seat, unless pressing circumstances exist to move the arbitration to another site, the ICAC will most likely hold proceedings in Moscow. ${ }^{140}$

\section{Language of the proceedings}

Under the old provisions, the SCCI would only hold proceedings in a language other than Russian with the consent of both parties. ${ }^{141}$ If a Russian party withheld their consent, then they would be assured of an arbitration in their own language. ${ }^{142}$ This compounded the difficulties Western parties faced in dealing with a foreign arbitral tribunal.

Koman, supra note 72 at 28.

See Viechtbauer, supra note 33 at 412 . Here, Viechtbauer discusses the infamous Soviet-lsrael oil case. Due to political tensions over the Suez Canal War, the Soviets cut off petroleum exports to Israel. The Soviet international commercial arbitration tribunal, in the case of Jordan Investments Ltd. v. Sojuzneftesport, aided the Soviet cause by manipulating the arbitral procedures in favor of the Soviet party.

Koman, supra note 72 at 28.

Zinger, supra note 36 at 173.

Koman, supra note 72 at 29.

1993 Decree, supra note 61, art. 20(1).

Ibid., art. 20(2).

Koman, supra note 72 at 29.

Ibid.

Ibid. 
The 1993 Decree amended this procedure. Article 22(1) allows the parties to stipulate the language of the proceedings by mutual agreement. If the parties fail to agree on this point, the ICAC "shall determine the language(s) which shall be used in proceedings. Such agreement or decision shall apply to any written statement made by a party, any hearing and any decision or ruling passed by the arbitration court." 143 Although this does not preclude the ICAC from choosing Russian as the language of the proceedings, it is at least a change from the old default rule. As well, the ICAC Rules provide that when one party does not understand the language of the proceedings, the ICAC shall, "at the party's request and expense, provide him with the services of an interpreter." 144

Considering the immense importance of the language issue, Alberta companies should bargain very strongly for English to be used as the language of the arbitration.

\section{Awarding Costs}

Contrary to the common European practice of awarding costs against the losing party, Soviet and Russian law, until recently, forced parties to pay their proper apportionment of the costs. ${ }^{145}$ This was changed in 1995 with the enactment of $\S 6$ of the Appendix to the ICAC Rules which states that, "If not otherwise provided by the parties, the arbitration fee shall be borne by the losing party." 146 $\S 6(2)$ of the Appendix to the ICAC Rules provides for rules governing the award of costs that have been partially fulfilled. If an Alberta company is wary of being liable for costs in a lost arbitration, then it should seek to draft the arbitration agreement appropriately.

\section{Appeals}

Historically, it was impossible to appeal the arbitral awards made by the SCCI on questions of substance or procedure. ${ }^{147}$ This hard-line approach was obviously quite unpopular with Western companies and was amended in the 1993 Decree. ${ }^{148}$ Under art. 34, the award may be challenged on a number of procedural fronts, thereby ensuring some basic rights to procedural fairness in the arbitration proceedings. The grounds for challenging are essentially as follows:

(1) the arbitration agreement was invalid;

(2) the applicant was not properly informed about the appointment of an arbitrator or the composition of the arbitration board or its procedures did not accord with the arbitration agreement;

(3) the award was issued in respect to a matter that cannot be arbitrated under the arbitration agreement, or was made on issues outside its operation;

1993 Decree, supra note 61, art. 22(1).

ICAC Rules, supra note 63 at $\$ 10$.

Koman, supra note 72 at 32 . Even under the 1993 Decree costs were still divided among the parties.

ICAC Rules, supra note 63, Appendix $\S 6(1)$.

Viechtbauer, supra note 33 at 416.

Koman, supra note 72 at 32 . 
(4) the subject-matter of the issue is not arbitrable under Russian law or is contrary to Russian public policy. ${ }^{149}$

As discussed below, these appeal provisions mimic the grounds for denial of enforcement of foreign arbitral awards pursuant to the New York Convention. ${ }^{150}$

For an Alberta party appealing an ICAC decision, these rules probably represent an adequate protection of procedural fairness. ${ }^{151}$ A note of caution might be raised if a Russian party were appealing on the basis of a public policy argument. As seen below, the concept of public policy is not very well defined in Russian law, and its newfound interpretations could be used to the detriment of an Alberta company.

Outside of the grounds for appeal set out in art. 34, the arbitral decisions of the ICAC are binding and final. There is no recourse to review questions of law decided by the ICAC. This is in line with the goal of the UNCITRAL Model Law to reduce the participation of national courts to a minimum.

\section{The Award - Tax and Currency Implications}

Although not within the scope of discussion of this article, an arbitral award of the ICAC could be subject to the wildly erratic tax laws of the Russian Federation. In light of the heavy duties imposed on Western companies, the payment of the award inside Russia may lead to some considerable loss on the part of an Alberta company. To protect itself, an Alberta company may wish to draft a clause into the arbitration agreement stipulating that the payment of awards should be made through foreign financial institutions outside Russia.

As well, attention should be paid to the denomination of the award. Given the fluctuating rates of the rouble, an Alberta company would be much better off with an award in hard currency.

The ICAC Rules give some guidance as to the ICAC's position on the relationship between the award and its denomination. $\S 3(5)$ of the Appendix to the ICAC Rules declares that "the arbitration fee shall be paid in Russian roubles, if the claim amount is expressed in Russian roubles. When the claim amount is recalculated in USD, the use shall be made of the exchange rate of the Central bank of Russia as of the date of the claim." ${ }^{152}$ This provision at least allows the parties to agree on the use of American dollars as the currency of choice for the arbitral award. The use of hard currency should definitely be drafted into the arbitration agreement by Alberta companies. 


\section{GENERAL SUMMARY OF ARBITRATING 'WITH THE ICAC}

The Russians make frequent use of the phrase, "v prinsipye." In English, this roughly translates to "in principle," but it is said with a healthy inflection of cynicism. "In principle," the new rules presented by the 1993 Decree and the ICAC Rules form the basis for fair and predictable problems yet to be resolved. An arbitration agreement must be fashioned with much care, precision and foresight. In light of the fast-paced changes in Russia, this is a difficult task. Long term petroleum contracts may be subject to the whim of unforeseeable changes in arbitration legislation. With careful negotiating and drafting on the part of an Alberta party, arbitrating at the ICAC could be quite functional.

\section{ENFORCEMENT OF ARBITRAL AWARDS IN RUSSIA}

Having examined the arbitration process at the ICAC, this article will now turn to the enforcement of arbitral awards in Russia. First, it will detail the interim measures available to an Alberta party, whether arbitrating in Russia or abroad. Then it will discuss the procedures for enforcing arbitral awards, both domestic (from the ICAC) and foreign. In doing so, it will investigate the relevant treaties and legislation, the application process, potential arguments in the enforcement process, and execution procedures.

\section{A. INTERIM MEASURES}

\section{Relevant Legislation}

Interim measures are of particular importance to an Alberta party in the midst of arbitrating either at the ICAC (in Russia) or some other venue. Bearing in mind Russia's unstable commercial environment, an Alberta company would be wise to take steps to preserve the assets of its Russian counterpart to prevent their disposal or disappearance. ${ }^{153}$

Before the 1993 Decree, the SCCI was invested with its won power to execute applications for interim measures, enabling it to grant security interests without leave of the courts. ${ }^{154}$ However, art. 9 of the 1993 Decree changed this by declaring that parties must apply in the courts for interim measures. ${ }^{155}$ Further, Russian courts are unlikely to enforce interim measures awarded by foreign courts. ${ }^{156}$

It follows that Alberta companies seeking to secure assets located in Russia must make their application in Russian courts. Having determined the proper country for the application, the next question is: which court has jurisdiction over interim measures? 
Hobér notes that there has been considerable confusion over this question, mainly due to a discrepancy between the Russian Civil Code and the 1993 Decree. ${ }^{157}$ The probable answer to the question is that Russian courts can, and ought to, hear applications for interim measures. ${ }^{158}$ As stated in Part IV, the appropriate court for the application of interim measures is the SAC.

In terms of applicable laws, c. 13 of the Russian Civil Code provides general fiats on security measures. ${ }^{159}$ Article 433 of the same document guarantees foreigners "the same procedural rights as Soviet [or Russian] citizens." 160 The new Arbitral Procedure Code states that the SAC may grant an interim injunction where "failure to take such measures would make satisfaction of a court judgment difficult or impossible."161 In addition, such an application must be "considered by the court not later than the day after the request is made ... and [may] be enforced immediately." 162

Thus, if an Alberta company were seeking a speedy injunction or security interest in the assets of a Russian entity, it could do so through the SAC.

\section{Problems Related to Interim Measures Applications}

As with every other issue encountered, there is a downside in making an application for interim measures in Russian courts. Although the process seems fairly well laid out, an Alberta company making a complicated application for interim measures might be frustrated by the lack of experience of the SAC in matters dealing with security interests, injunctions and seizures. The seventy year reign of the Communist regime isolated almost all decision-making bodies from the realities of Western commercial law, leaving the current courts with next to no experience in this area. ${ }^{163}$ In an application for a security interest, for example, a judge might incorrectly apply the law, forcing an Alberta party to make a costly appeal. Although inconvenient, an Alberta company may have little or no choice but to proceed with an application in Russia.

\section{B. DOMESTIC ARBITRATION ENFORCEMENT}

Due to recent legislation, the treatment of arbitral awards made by the ICAC is exactly the same as any other award. Article 35 of the 1993 Decree states, "Regardless of where the arbitration award was issued, it shall be recognized as binding and, after a written application is filed to a competent court, shall be enforced subject to the provisions of the present Article and Article 36."164 Accordingly, this article will combine the legal analysis of this section with the section below.

Hobér, supra note 43 at $\mathbf{4 4 - 4 5}$.

lbid. at $46-47$.

Ibid. at 44.

Ibid.

Kirillova \& Aitken, supra note 49 at 2.

Ibid.

Zinger, supra note 36 at 172.

1993 Decree, supra note 61, art. 35(1). 


\section{ENFORCEMENT OF FOREIGN ARBITRAL AWARDS}

This section concentrates on the enforcement of arbitral awards in Russia, made by other international commercial arbitration boards abroad. Firstly, it reviews the relevant international agreements and legislation on the topic. Secondly, it examines the application process, as well as potential legal arguments for both the defendant and plaintiff. Finally, it investigates execution procedures in Russia.

\section{Legislation and Treaties Relevant to Enforcement}

\section{a. The 1958 New York Convention}

The New York Convention facilitates the worldwide enforcement of arbitral awards by requiring its signatories to uphold foreign arbitral awards and to institute local legislation setting out the process for enforcement. ${ }^{165}$

In 1960, the Soviet Union acceded to the New York Convention. At that time, the Soviet government stipulated a reservation, as per art. XVI, that it would only apply the "provisions of [the] Convention in respect to arbitral awards made in the territories of non-contracting States only to the extent to which they grant reciprocal treatment."166 This reservation of reciprocity affected Canada until 1986, when it acceded to the New York Convention. Consequently, there was no further issue of reciprocity, since both Canada and the Soviet Union were bound to enforce each others judgments.

\section{b. The 1988 Decree}

Pursuant to its obligations in the New York Convention, in 1988 the Supreme Soviet passed a decree setting out the procedures for the enforcement of foreign arbitral awards. ${ }^{167}$ The considerable delay in the implementation of the 1988 Decree was mainly due to the lack of its necessity. Until 1990, no Soviet trading company had ever failed to pay an arbitral award passed by another arbitration board. ${ }^{168}$

The 1988 Decree states that the enforcement of foreign arbitral awards falls within the jurisdiction of the Supreme Courts. ${ }^{169}$ Significantly, the 1988 Decree also provides for a limitation period of three years in which to present a foreign award for execution by the court. ${ }^{170}$

Zinger, supra note 36 at 169.

United Nations, Multilateral Treaties Deposited with the Secretary-General (Status as at 31 December 1989) (N.Y.: United Nations, 1996) at 833. See also Hobér, supra note 43 at 129.

1988 Decree, supra note 51.

Hoberr, supra note 43 at 5.

Viechtbauer, supra note 33 at 425 . Here, several other levels of court available for the enforcement of the award have been omitted; this was done to concentrate this article on the topic of enforcement, and not on the structure of the Russian court system. See Hobér, ibid.

Viechtbauer, ibid. at 426. 
c. The 1993 Decree

The 1993 Decree also bears on the enforcement of foreign arbitral awards. Given that the 1993 Decree represents the latest law on the subject, the 1988 Decree should be seen as a supplement to its newer legislative cousin. ${ }^{171}$

Article 35 of the 1993 Decree sets out the right of any party to enforce a foreign arbitral award by presenting the competent court with the original, or certified, copy of the award and the arbitration agreement. ${ }^{172}$ It is noteworthy that art. 35 does not stipulate any exact process for the enforcement of the award.

Article 36 of the 1993 Decree sets out the grounds for denial of recognition of the award. ${ }^{173}$ As noted above, these grounds are identical to those contained in the New York Convention. They cover basic concerns regarding procedural fairness and do not give a right of general appeal. ${ }^{174}$ In the final analysis, the 1993 Decree is a combination of both the UNCITRAL Model Law and the New York Convention.

\section{The Application Process}

The next issue is the enforcement application itself. The first hurdle is to determine the proper forum for the application. As noted, the 1993 Decree only provides that the application be presented to a "competent court." ${ }^{175}$ It does not stipulate which court this is, or give any indication of the procedure for the application, aside from the presentation of the arbitral award and arbitration agreement. The Russian Civil Code is similarly vague: "foreign court [or arbitration] decisions, when properly presented to the local courts ... may likewise be executed by the court or its bailiff."176

Given the recent restructuring of the SAC and its expanding jurisdiction, it may be the most appropriate court for hearing an enforcement application. ${ }^{177}$ As to the appropriate court level of the SAC, the wording of the 1988 Decree gives the power of arbitral enforcement to the Supreme Courts. ${ }^{178}$ The combination of this provision and the general subject matter jurisdiction may make the Supreme Court of the SAC the best choice available. ${ }^{179}$

\footnotetext{
171 Hobér, supra note 43 at 16.

1721993 Decree, supra note 61, arts. $35(1) \&$ (2).

17 Ibid., art. 36.

$174 \quad$ See supra note 149 and associated text.

1751993 Decree, supra note 61, art. 35(1).

$176 \quad$ Zinger, supra note 36 at 159.

in See supra note 163 and associated text.

$17 \quad 1988$ Decree, supra note 51.

179 As will be discussed infra, Hober cites cases on arbitral enforcement that were litigated in the Moscow City Courts. In the structure of Russia's judicial system, a city court remains the rough equivalent to the Supreme Court of the SAC, leaving an Alberta company with potentially two options.
} 
As mentioned, there really is no process or specific procedure set out for an enforcement application. The provision of the Russian Civil Code, quoted above, indicates that an application must be presented to the courts through "diplömatic channels." This phrase is nebulous at best and, without any supporting definition, hardly qualifies as a specific "procedure." The 1993 Decree provides that the applicant party must present an original, or certified, copy of both the arbitral award and the arbitration agreement, but does not detail the process. ${ }^{180}$ Whatever the procedure, it is important to remember the three year limitation period placed on enforcement applications. Given the confusion over the actual enforcement process, this three year limit is actually quite short.

\section{Potential Legal Arguments in the Enforcement Process}

Having won an arbitration, either in Russia or elsewhere, an Alberta company might have concerns about the views of the Russian courts vis-à-vis certain defences; such as State Immunity, Act of State, etc. ${ }^{181}$ This section will examine these concerns by looking at substantive arguments and then at the procedural arguments that a Russian entity might raise in enforcement proceedings.

\section{a. Substantive Arguments}

\section{i. Foreign Trade Organizations and State Immunity}

Some companies operating in Russia today owe their creation to the Soviet government. During the economic restructuring of the Soviet Union in the late 1980s and early 1990s, certain Soviet companies were given the power to economically interact with the international community without the heavy supervision of the government. ${ }^{182}$ These companies were called Foreign Trade Organizations (FTOs), and some of them included petroleum companies. Some FTOs were later converted into joint-stock companies by the Russian government. ${ }^{183}$

In enforcement proceedings, these FTOs (or former FTOs) may argue that their proximity to the Russian government affords them protection under such doctrines as State Immunity, Act of State, or Government Debt. ${ }^{184}$ The success of this argument would limit Alberta parties seeking enforcement of awards against FTOs, or former FTOs.

1993 Decree, supra note 61, art. 35(2).

It is not the aim of this article to delve into the details of public international law on state sovereignty issues. Moreover, it will concentrate on the proximity of Russian companies to the Russian government to discover whether such close relations might insulate these companies from arbitral enforcement. For a general discussion of State Immunity and international commercial arbitration, see Ebenroth \& Dillon, supra note 30.

Hobér, supra note 43 at 9.

Ibid. at 83. For example, see Charter of the Russian Joint-Stock Society "Gazprom," Confirmed by Decree of the Council of Ministers - Government of the Russian Federation, 17 February 1993, No. 138.

Ibid. 
A 1993 decision of the Russian Supreme Court provides some answers to these questions. ${ }^{185}$ In this case, an FTO argued that a Swedish company could not enforce its arbitral award, because the FTO had sufficient proximity to the state that its debts should be considered a debt of the state, and would therefore be immune to enforcement by the courts. The Court disagreed with this analysis, stating that "under the terms of the contract concluded by the defendant it appears as a party and a buyer."186 Although the above case represents only one decision, the court seems to espouse a pro-enforcement stance on arbitral awards.

Considering the proximity of an FTO to the Russian government, an Alberta company might consider trying to "lift the corporate veil" to get at the government itself. If the FTO does not possess sufficient assets to fulfill its obligations, can an Alberta company go after "the bigger fish"? There is no case law on this issue, but art. 33 of the Russian Civil Code specifically states that the government is not responsible for the debts of state enterprises. ${ }^{187}$ From the case above, it is clear that the Russian Supreme Court regards FTOs as separate entities. Therefore, it is improbable that an Alberta company would be successful with such an application.

\section{ii. Succession to the New York Convention by the Russian Government}

Although the Soviet Union acceded to the New York Convention in 1960, there may be some questions concerning Russia's succession to the treaty. Russian companies might rely on this uncertainty in enforcement proceedings to argue that Russian courts are not bound to the compulsory execution of the awards set out in the New York Convention.

This argument is considered weak for a number of reasons. When the Soviet Union was dismantled in 1991, Russia, Ukraine and Belorus signed a tripartite agreement called the Minsk Agreement. Article 12 of the Minsk Agreement provides for "the fulfillment of the international obligations binding upon them for the treaties and agreements of the former [Soviet Socialist Republics]." ${ }^{188}$ These obligations include those incurred by the Soviet accession to the New York Convention in 1960. This was confirmed by the Alma-Ata Declaration, which later formed the Commonwealth of Independent States. ${ }^{189} \mathrm{~A}$ recent status update also confirms Russia's continued obligations under the New York Convention. ${ }^{190}$

In the face of all of these statements of obligation, a Russian party did raise the succession issue in enforcement proceedings in 1992. This case is probably the first one in Russian/Soviet history dealing with the enforcement of a foreign arbitral decision

\footnotetext{
185 Case No. 8-3g93-17, in Hobér, supra note 43 at 188.

186 Ibid. at 190.

$187 \quad$ Ibid. at 68.

Iss The Minsk Agreement on Establishing a Commonwealth of Independent States, in Hober, supra note 43 at 157.

189 Alma-Ata Declaration, in Hobér, ibid. at 161.

190 "Status Update: Convention on the Recognition and Enforcement of Foreign Arbitral Awards, (New York 1958)" (1996) 2:1 Can. Int'1 Lawy. 50 at 50.
} 
made in a non-socialist country. ${ }^{191}$ Again, the Moscow City Court denied the Russian claim. ${ }^{192}$ In its decision, the Court relied on art. 12 of the Minsk Agreement to confirm Russia's succession to the treaty. ${ }^{193}$

\section{iii. Defences of Jurisdiction and Enforcement}

In case no. 8-3g93-17, discussed above, the Moscow City Court made interesting comments on the use of so-called substantive defences such as State Immunity. The Court pointed out that even if the FTO was successful in deflecting its obligations towards the state, it would only give the FTO "the ground to appeal against the decision of the arbitral tribunal ... and not for objecting to its compulsory execution. ${ }^{\text {"194 }}$ In other words, any substantive defences that a Russian party might use would only go to the issue of jurisdiction and not enforcement.

The approach of the Moscow City Court indicates that the only grounds for denial of an award enforcement are those set out in the New York Convention. This precludes Russian parties from raising any of the arguments explained. ${ }^{195}$

iv. Procedural Arguments

The implications of the Moscow City Court's decision indicate that enforcement of an award may only be denied, as per art. 36(1)(a) of the 1993 Decree, where:

(1) one of the parties to the arbitration agreement ... was incompetent; or such agreement is invalid ... by operation of the law of the country where the award was issued; or

(2) the losing party was not properly informed about the appointment of an arbitrator; or

(3) the award was issued in respect of the dispute which is not provided for by the arbitration agreement; or

(4) the composition of the arbitration court or the arbitration proceedings fail to correspond to the agreement of the parties. ${ }^{196}$

It is evident that the grounds for denial set out by the 1993 Decree are procedural in nature. Since the 1993 Decree mirrors the New York Convention, these grounds are the same as those generally accepted worldwide. Subsequently, there are no aspects to art. 36(1)(a) that are grossly disadvantageous.

However, art. 36(1)(b) provides for the denial of enforcement in the case where it would "conflict with the public order of the Russian Federation."197 This is

Hobér, supra note 43 at 21.

Ibid.

Ibid.

Case No. 8-3g93-17, supra note 185 at 190.

Hobér, supra note 43 at 58.

1993 Decree, supra note 61, art. 36(1)(a).

Ibid., art. 36(1)(b).
} 
problematic because the term "public order" is not defined in the 1993 Decree, nor in any other relevant piece of Russian legislation, leaving its interpretation open to the courts. How should "public order" be construed in a country experiencing total political upheaval? Would it be counter to the public order to force the liquidation of a Russian company, leaving the salaries of its employees in arrears? Similarly, art. 34 provides that enforcement may be denied if the subject matter of the dispute is not capable of settlement by arbitration under the laws of the Russian Federation. ${ }^{198}$ Given the legislative chaos of Russia, it may be difficult to ascertain what types of disputes are or are not arbitrable. The answers to these questions are simply unknown at this stage of Russia's legal development, and remain a legal thorn in the side of enforcement proceedings.

\section{EXECUTION OF THE ENFORCEMENT ORDER}

The execution of enforcement orders in Russian civil law is in a considerable state of disarray. What may be subject to execution is largely determined by the type of company against which an arbitral award is applied. For example, art. 409 of the Russian Civil Code states that execution of awards against FTOs should be carried out on its bank accounts before its physical property. ${ }^{199}$ In regards to joint-stock companies, and other companies, it would seem that there are no restrictions on the subject matter of execution. ${ }^{200}$

The larger complaints in the area of execution result from a general lack of legislative procedure. Article 15(1) of the Fundamentals stipulates that all the assets of juridical persons may be seized. ${ }^{201}$ Similarly, c. 16 of the Russian Code of Arbitral Procedure allows the courts to make an order for the seizure of the losing party's bank accounts. ${ }^{202}$ However, neither of these provisions sets out how these seizures are to take place. Hober notes that the system governing the courts, execution authorities, and bailiffs is relatively new and untried. ${ }^{203}$

The lack of guidance in execution procedures makes the whole process very novel to Russian courts, and therefore risky to Alberta creditors. This is compounded by the general lack of experience of the Russian courts in complicated creditor-debtor relationships.

\section{E. GENERAL PROBLEMS}

A common theme throughout this article has been the real and widespread issue of corruption in Russia's courts. The problem is so bad that an emerging market fund

\footnotetext{
198 Ibid., art. 34(2).

199 Hobér, supra note 43 at 60-61.

200 Statute on Joint-Stock Societies, Confirmed by Decree of the RSFSR Council of Ministers, No. 601. 25 December, 1990. SP RSFSR (1991) no.6 item 92, in W.E. Butler, ed., Collected Legislation of Russia (New York: Oceana Publications, 1992) at 27.

$201 \quad$ Bardina, supra note 85 at 669.

$202 \quad$ Zinger, supra note 36 at 159.

${ }_{203}$ Hober, supra note 43 at 44.
} 
analyst was recently quoted as saying "Forget it. Don't even think about getting justice in a Russian court."204 Corruption could rear its ugly head in enforcement proceedings. Given the amount of money at risk, even the Russian Mafia might play some role. In a country where the parties attend court escorted by bodyguards, anything seems possible. ${ }^{205}$

Other exacerbating factors may be inexperience and bureaucracy. As aforementioned, an inexperienced judiciary could easily misconstrue legal principles or misapply new laws, all to the detriment of an Alberta party. In addition, the enforcement process could be lengthy. Although applications for interim measures are to be heard within one day of their request, there are no limits set out for the enforcement procedure itself. The tomes of competing legislation make it difficult for the parties, and the judiciary, to choose which standards govern their legal predicaments. ${ }^{206}$ In turn, this makes legal proceedings anything but timely.

\section{F. SUMMARY OF THE ENFORCEMENT PROCEDURE}

As observed in the sections above, enforcement procedures in Russia have developed in a legislative patchwork. On the positive side, from the few Russian decisions on enforcement, the courts display a pro-enforcement stance on foreign arbitral awards. However, there is a general lack of specific procedural laws governing applications for interim measures, arbitral award enforcement and execution.

Once again, we are met with the old Russian phrase. "In principle," the legislative patchwork allows for enforcement, but in practice no one knows how this is accomplished. Perhaps developments in Russian civil legislation will remedy this. Whole new sections of the Russian Civil Code have been drafted, and their implementation and publication is forthcoming. ${ }^{207}$

If Alberta companies are particularly worried about the legal status of arbitral enforcement within the Russian Federation, then they can lobby the federal government of Canada for a bilateral treaty with Russia on the subject. Article VII(1) of the New York Convention specifically allows for the validity of other multilateral and bilateral treaties between the signatory states. ${ }^{208}$ Indeed, the United States concluded such an agreement with the Russian Federation. ${ }^{209} \mathrm{~A}$ bilateral treaty could create a framework for basic procedures on the enforcement and execution of arbitral awards.

\footnotetext{
Kaban, supra note 52 at 14.

Ibid.

Zinger, supra note 36 at 177.

E. Craik, "Civil Code: New Basic Law" Moscow Times (1 November 1994) 581.

New York Convention, supra note 70.

For a more thorough examination of this treaty see Zinger, supra note 36 at 180 .
} 


\section{CONCLUSION}

The title of this article, "The First Pancake Always Has Lumps," alludes to a Russian proverb which describes the results of any inaugural experiment. This aptly illustrates the current status of the arbitration experiment in the Russian Federation.

Russia has a long and reputable history of international commercial arbitration dating from the 1930s. The passing of the 1993 Decree and the new ICAC Rules demonstrate the Russian government's desire to build on that history. Undoubtedly, the goal of these legislative changes is to attract Western capital investment with the promise of legal stability.

The area of arbitral award enforcement illustrates a similar commitment. The signing of the New York Convention and the resulting 1988 Decree indicate the Soviet resolve to uphold arbitral awards. The Russian government and the courts upheld this resolution by validating arbitral awards; not allowing public policy rules to interfere with enforcement.

In terms of the metaphor, these achievements would constitute the "first pancake." The question is, where are the lumps? In the arbitration process, this article discussed a whole host of difficulties ranging from the applicable law and procedural matters, to language barriers and the awarding of costs. With respect to arbitral award enforcement, it detailed the general lack of legal procedure available to Alberta companies to ensure the fruition of their arbitrations.

Despite these difficulties, Alberta companies can mitigate the risk. Arbitration agreements can be infused with contractual protections that reduce the risk to Alberta capital. In terms of arbitral award enforcement, the Russian courts have shown a deep commitment to the enforcement of arbitral awards. So, although this pancake does have lumps, the lumps can be flattened with the care and attention of a lawyer. 
APPENDIX A

COURT SYSTEM OF THE RUSSIAN FEDERATION ${ }^{210}$

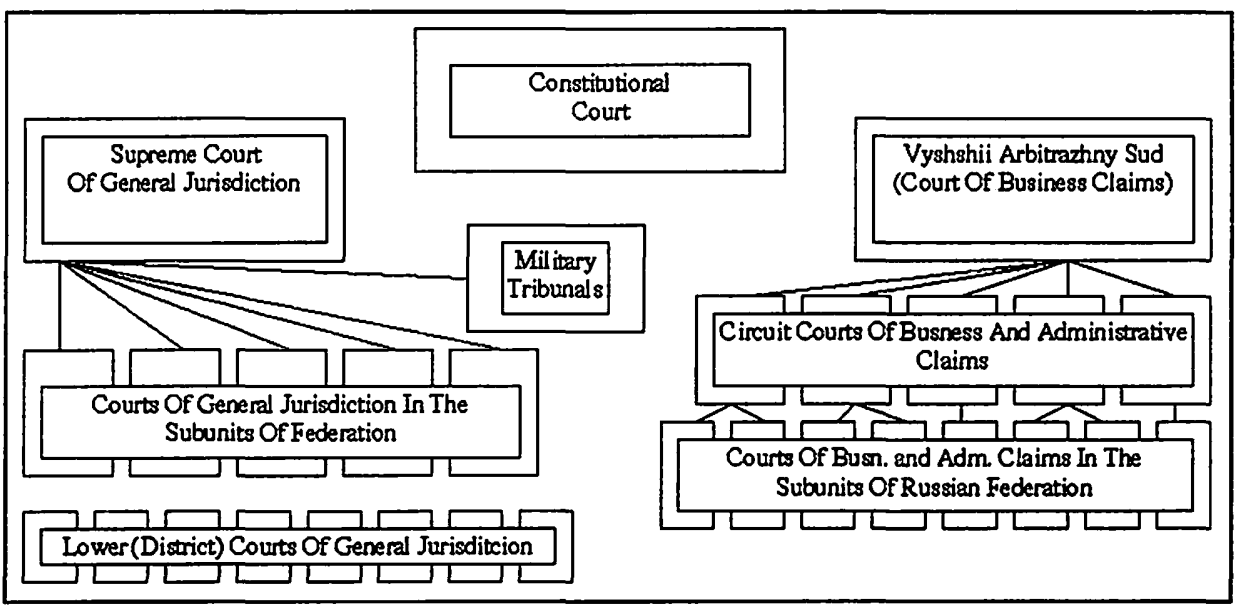

210 I.V. Nikiforov, (1995) Russian Legal Information Sources (http:// solar.rtd.utk.edu/ -sanor/research/systems.htm\#MAIL). 